\title{
RETRATOS DE AUTOR: AUTORRETRATOS DE JEAN COCTEAU ${ }^{1}$
}

Wellington Júnio Costa

Mestrando em Teoria da Literatura do Programa de Pós-Graduação em Estudos Literários /

UFMG

\begin{abstract}
RESUMO
Artista pluridisciplinar, o poeta francês Jean Cocteau construiu uma obra em que a expressão do “eu” é um tema central. Este artigo propõe uma reflexão sobre as questões suscitadas por uma série de autorretratos que o autor produziu entre 1910 e 1917, tais como identidade, imagem, memória e narrativa.
\end{abstract}

\section{PALAVRAS-CHAVE}

Jean Cocteau, autorretrato, identidade, imagem, memória

A humanidade construiu um mundo de imagens. Entre elas, a imagem do próprio homem ocupa um lugar central nesse mundo, que se revela, às vezes, como um mosaico de autorretratos. Segundo Ernst Rebel, ${ }^{2}$ enquanto gênero artístico, o mais antigo autorretrato da história da arte na Europa é a tela O homem do turbante vermelho, pintada por Jan Van Eyck em 1433, momento em que a palavra “artista” já designava uma profissão. Mas, para Pascal Bonafoux, ${ }^{3}$ mesmo que os gregos, na Antiguidade, ou os monges copistas nos séculos 11 e 12 e muitos artistas depois deles tenham se autorrepresentado, o autorretrato só pode ser reconhecido como gênero por volta de 1950, com a entrada do termo “autoportrait” num dicionário da língua francesa. Já Yves Calméjane ${ }^{4}$ considera que a questão “Quem sou eu?” se preparava desde a Era das cavernas, quando o homem se representou em traços esquemáticos, em cenas de caças ou, simplesmente, quando deixou as marcas de suas mãos nas paredes de

\footnotetext{
${ }^{1}$ Este artigo tem como base a pesquisa " Je(an) Cocteau: a construção do eu no desenho, na literatura e no cinema”. Orientadora: professora Márcia M. V. Arbex.

${ }^{2}$ REBEL. Autoportraits, p. 6-10.

${ }^{3}$ BONAFOUX. Autoportraits du XXe siècle. Look at me.

${ }^{4}$ CALMÉJANE. Histoire de moi. L'histoire des autoportraits.
} 
suas rudes habitações. Mais tarde, ainda segundo Calméjane, o caso de Ni-Ankh-Plath, no Egito antigo, ilustraria a primeira tentativa consciente de autorrepresentação e a primeira obra assinada de que se tem notícia. Na Grécia antiga, o escultor Fídias teria sido condenado à prisão por ter esculpido seu próprio rosto num detalhe da escultura que fizera da Deusa Atena. Essa “atração narcisista pela própria imagem; tentativa de sair de si mesmo para enfim ver-se melhor" ${ }^{\text {, }}$ e compreender-se, atravessou todas as épocas até a atualidade e fez-se muito presente no século 20.

Neste artigo pretendo analisar uma série de autorretratos do poeta ${ }^{6}$ francês Jean Cocteau, como gênero e como exemplo de obras que suscitam o questionamento das relações entre imagem, identidade, memória e narrativa, questões levantadas e discutidas no decorrer da disciplina "Imagem e Memória” ministrada pelos professores Elisa Amorim e Élcio Cornelsen no Mestrado de Teoria da Literatura do curso de Pós-graduação em Estudos Literários da Faculdade de Letras da Universidade Federal de Minas Gerais, à luz de autores como Georges Didi-Huberman, ${ }^{7}$ Peter Burke, ${ }^{8}$ Alberto Manguel, ${ }^{9}$ entre outros.

Nascido em Maison-Laffitte, a 17 quilômetros de Paris, no dia 5 de julho de 1889, Jean Cocteau participou ativamente de várias correntes e manifestações artísticas de vanguarda até a sua morte, no dia 11 de outubro de 1963, na sua casa, hoje aberta à visitação, em Milly-La-Forêt, a pouco mais de 50 quilômetros da capital francesa. Poeta, romancista, dramaturgo, ensaísta, pintor, escultor, desenhista, ilustrador, designer, fotógrafo, ator, roteirista e diretor de cinema, Cocteau escreveu ainda canções e argumentos para dança, realizando, assim, ainda na primeira metade do século 20, o sonho da maioria dos artistas de hoje: construir uma sólida carreira multimídia, ser um criador "transdisciplinar", unir a tradição e a vanguarda, falar de si mesmo como metonímia do mundo. Daí, a sua grande produção de autorretratos.

Peter Burke ${ }^{10}$ afirma que “o retrato pintado [desenhado] é um gênero artístico que, como outros gêneros, é composto de acordo com um sistema de convenções que muda

\footnotetext{
${ }^{5}$ TEIXEIRA COELHO. Olhar e ser visto na Casa Fiat de Cultura. A figura humana da renascença ao contemporâneo, p. 32.

${ }^{6}$ Embora se expressasse em quase todas as linguagens artísticas de seu tempo, Jean Cocteau se intitulava "poeta" e assim preferia ser chamado.

${ }^{7}$ DIDI-HUBERMANN. O que vemos, o que nos olha.

${ }^{8}$ BURKE. Testemunha ocular: história e imagem.

${ }^{9}$ MANGUEL. Leer imágenes. Una historia privada del arte.

${ }^{10}$ BURKE. Testemunha ocular: história e imagem, p. 31.
} 
lentamente com o tempo.” É o que se pode constatar através da composição convencional do seguinte autorretrato de Jean Cocteau, realizado em 1913.

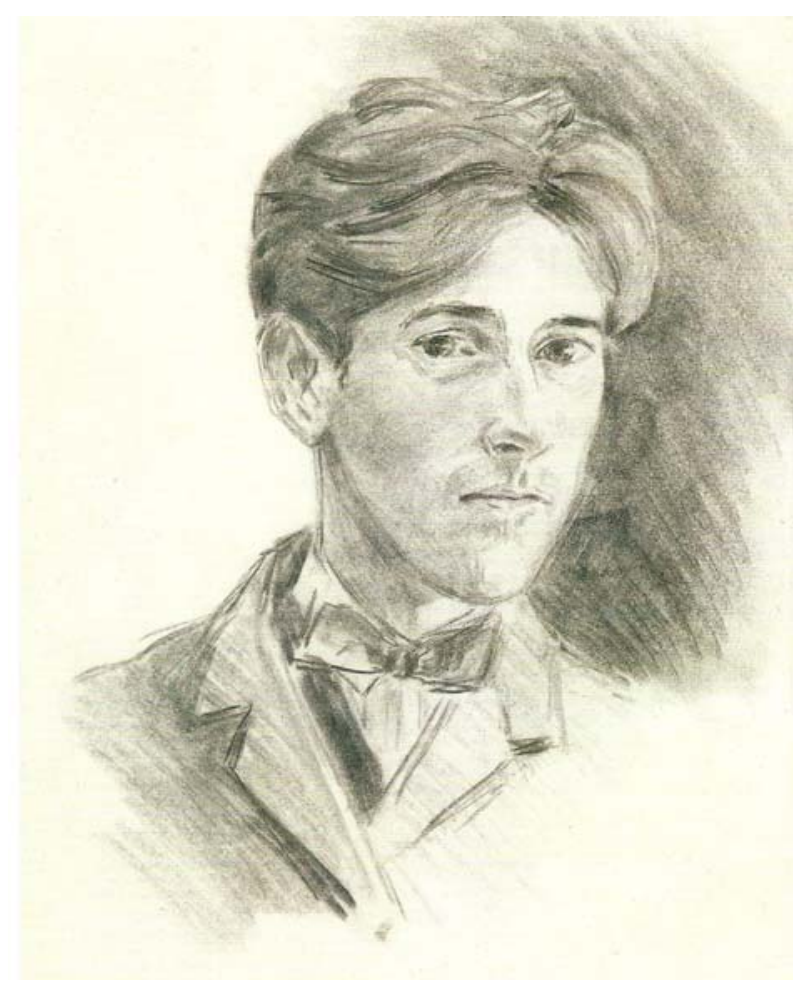

FIG. 1 - Autoportrait, 1913, carvão sobre papel, 34x24. Coleção particular.

Nessa imagem, vê-se o então jovem poeta de terno e gravata borboleta, o que pode indicar o seu pertencimento a uma classe social abastada. Mas isso não revela tudo.

Descobrir o que está escondido no que se mostra desperta o velho instinto de caçador adormecido em nós. (...) o pintor se apresenta e diz: "Vejam, sou eu!” Mas nem sempre é verdade, longe disso, e pode-se até mesmo afirmar que um autorretrato apenas muito raramente diz a verdade. Trata-se, frequentemente, de uma máscara, uma aparência, intencional ou não, que o artista apresenta e tem-se prazer em descobrir o que esses autores de autorretratos escondem dos outros ou de si mesmos, querendo tanto se mostrar... ${ }^{11}$

De alguma forma, Cocteau parecia conhecer as regras do jogo, pois em 1919 ele se apropriou de uma fotografia que haviam feito dele, transformando-a em uma espécie de autorretrato mascarado, o que explicitaria “a brincadeira de esconde-esconde” descrita por Calméjane.

${ }^{11}$ CALMÉJANE. Histoire de moi. L’histoire des autoportraits, p. 9, tradução nossa. 


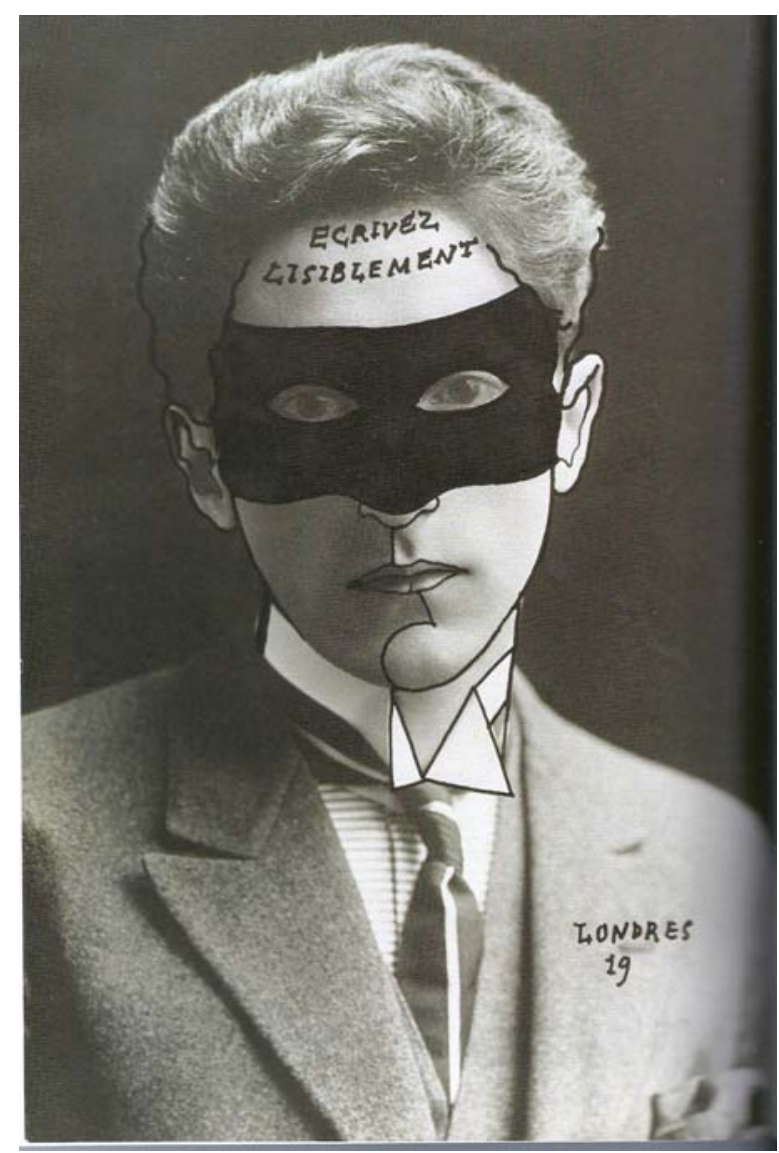

FIG. 2 - Fotografia retocada por Jean Cocteau, 1919.

Nessa foto, pode-se reconhecer o poeta, bem vestido como sempre. E, se acreditamos em suas interferências, sabemos quando e onde ele estava no momento em que a imagem foi produzida: Londres, 1919. Mas, o que queria o poeta esconder atrás dessa máscara? O que ele pretendia dizer com a frase "Escreva legivelmente”, marcada em sua testa? São perguntas que surgem inevitavelmente à vista da imagem e para as quais não se tem uma resposta.

Antes desta obra, no entanto, Cocteau já havia invertido as convenções do gênero autorretrato numa série de desenhos realizados entre 1910 e 1917. Uma série de autorretratos sem rosto, que nos remete ao conceito de imagem crítica de Didi-Huberman, uma vez que sendo um autorretrato, a imagem deveria apresentar justamente o que ela omite, ou seja, ela provoca uma crise.

[É]uma imagem em crise, uma imagem que critica a imagem - capaz portanto de um efeito, de uma eficácia teóricos -, e por isso uma imagem que critica nossas maneiras de vê-la, na medida em que, ao nos olhar, ela nos obriga a olhá-la verdadeiramente. E nos obriga a escrever esse olhar, não para 'transcrevê-lo', mas para constituí-lo. ${ }^{12}$

\footnotetext{
${ }^{12}$ DIDI-HUBERMANN. O que vemos, o que nos olha, p. 171-172.
} 


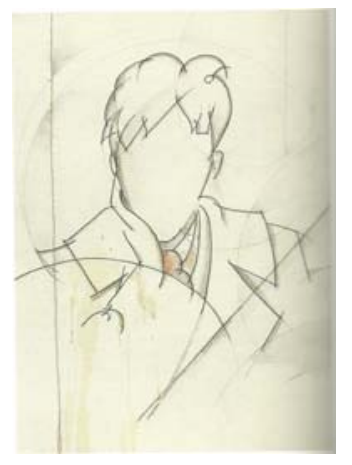

FIG. 3 - Autoportrait sans visage - cubiste, v. 1910-1912. Lápis de cor e lavis sobre cartão, 38x25,5. Coleçao particular.

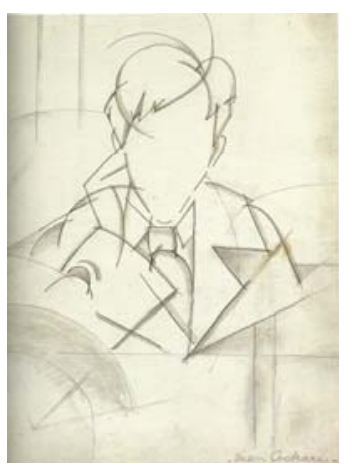

FIG. 4 - Autoportrait sans visage - cubiste, v. 1910-1913. Desenho, 37x27. Coleção Liliane e Étienne de Saint-Georges.

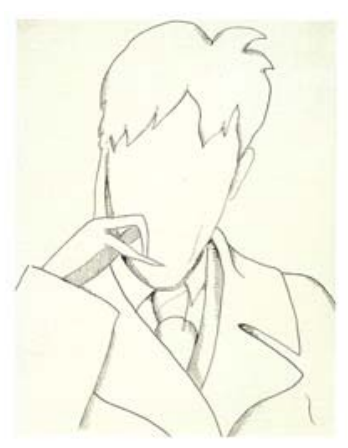

FIG. 5 - Autoportrait sans visage, v. 1910-1913. Desenho. Maison Jean Cocteau.

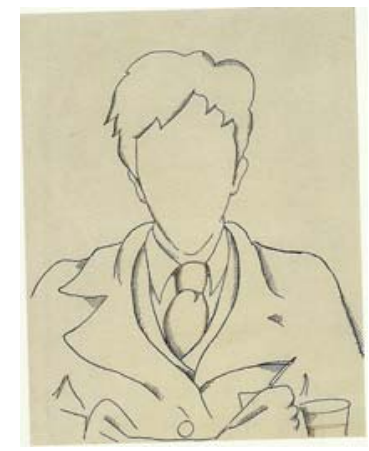

FIG. 6 - Autoportrait sans visage, v. 1910-1913. Nanquim e tinta vermelha, 27x21. Coleção particular. 
Ora, de um retrato esperamos ver o rosto, os traços que definem a fisionomia do modelo, que no caso do autorretrato é também o autor. Mas, aqui, apenas o seu contorno nos é dado a ver. Identificaríamos Cocteau, não fossem as obras intituladas “autorretrato” e seu autor revelado? Segundo Burke, “os acessórios representados junto com os modelos geralmente reforçam suas autorrepresentações”. ${ }^{13}$ De fato, podemos identificar certo estilo de vestir de Jean Cocteau, talvez o penteado ou ainda a sua pose nas fig. 3, 4 e 5, já que as tão célebres mãos do poeta garantem seu papel na composição. Mas, não saberíamos dizer se o poeta tem olhos grandes, lábios finos ou nariz adunco, no entanto, é o que se espera, em primeiro lugar, de uma descrição que visa a identificar alguém, como para um "retrato falado”, impossível de ser construído sem tais elementos.

De toda maneira, alguns anos mais tarde, Cocteau continuou sua série de autorretratos sem rosto e algumas questões permaneceram: Por que omitir seus próprios traços fisionômicos? Os acessórios ou o cenário um pouco mais desenvolvido, como na fig. 9, bastariam para a identificação? A revelação do autor e o título continuariam indispensáveis para o seu reconhecimento? Provavelmente sim.

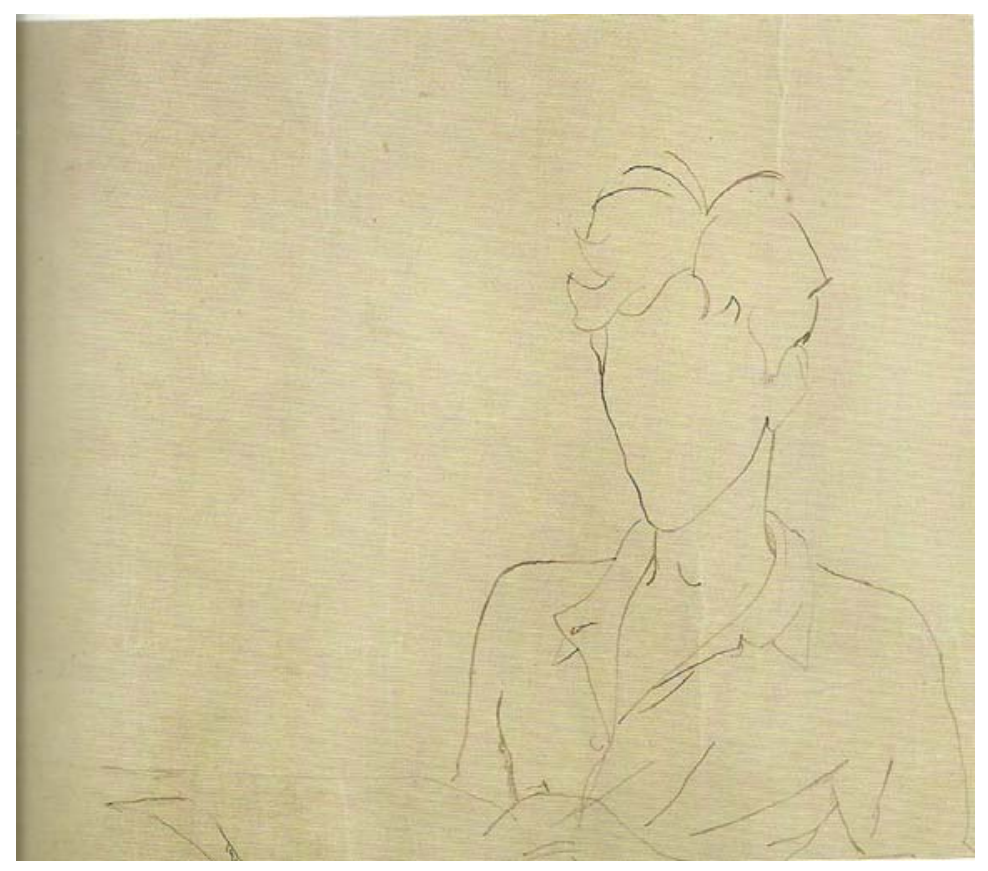

FIG. 7 - Autoportrait, v. 1915. Grafite. Maison Jean Cocteau.

\footnotetext{
${ }^{13}$ BURKE. Testemunha ocular: história e imagem, p. 32.
} 


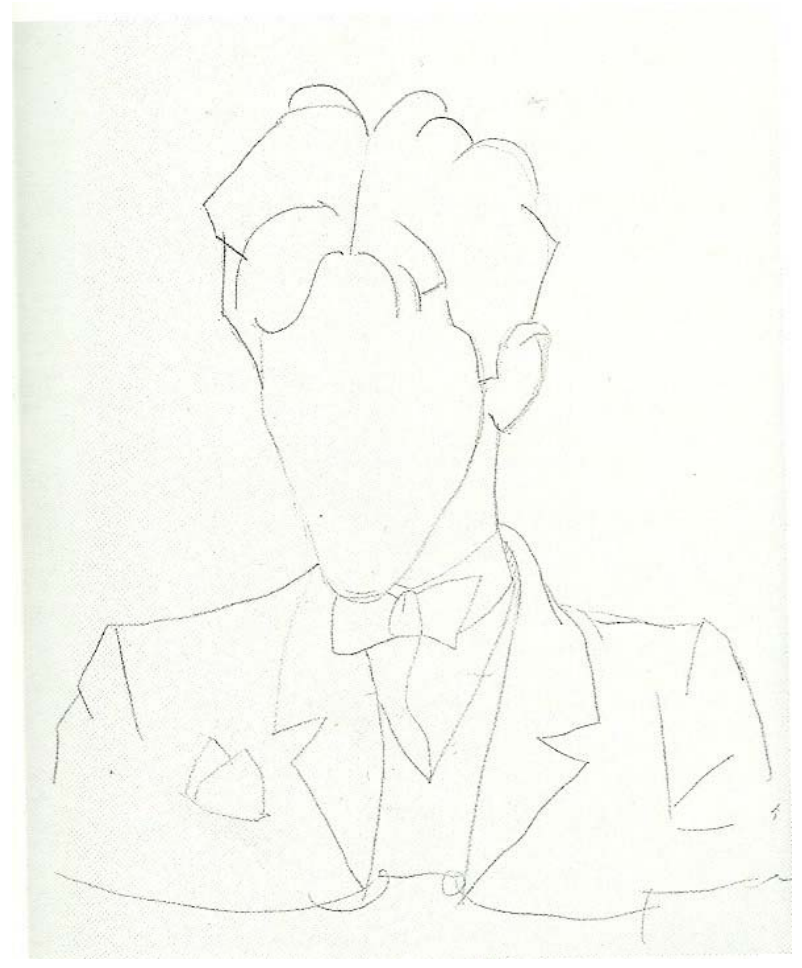

FIG. 8 - Autoportrait sans visage, 1917. Grafite, 27,5x23. Coleção particular.

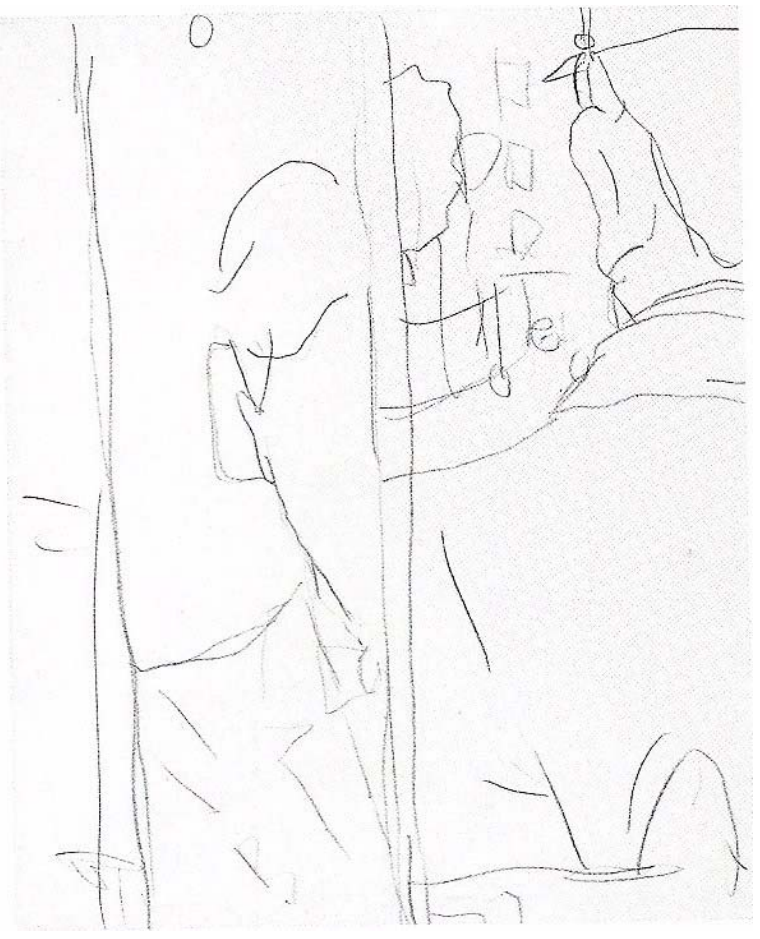

FIG. 9 - Autoportrait, 1917. Grafite, 27,5x23. Coleção particular.

Seria a escolha do poeta uma simples provocação estética? Ou a questão que se coloca é de ordem da identidade e memória? O desconhecimento ou esquecimento do "eu”? O fato é que traços foram "apagados” e com eles a possibilidade de se reconhecer uma semelhança 
física entre o retratado e quem quer que seja. Restando apenas elementos de indicação sociocultural como as roupas. No entanto, o poeta descreveu em seu livro La difficulté d'être, publicado pela primeira vez em 1947, as transformações dos seus traços físicos provocadas pelo passar do tempo e as semelhanças do seu rosto com o do seu avô e o da sua mãe:

Eu nunca tive um rosto bonito. Em mim, a juventude compensava a beleza. Minha ossatura é boa. São os músculos que se organizam mal sobre ela. Além disso, o esqueleto se transforma ao longo da vida e se estraga. Meu nariz, que sempre fora reto, curva-se como o do meu avô. E eu notei que o da minha mãe também se tinha curvado no seu leito de morte. ${ }^{14}$

Exatamente como havia provado ter consciência de sua própria aparência com o autorretrato de 1913, nesse livro, Cocteau revela ter, também, a consciência do seu amadurecimento físico. Por que teria ele, então, optado pela omissão de seus traços? Talvez para retratar sua “invisibilidade”. Afinal, sempre disse ser o poeta mais desconhecido e ao mesmo tempo o mais célebre de sua época. ${ }^{15}$

Um desenho (Fig. 10), com as mesmas características dos que compõem essa série de autorretratos sem rosto, omite, também, a data da sua realização. Seria proposital? Outro “esquecimento”, “apagamento” ou uma reflexão-provocação sobre o tempo?

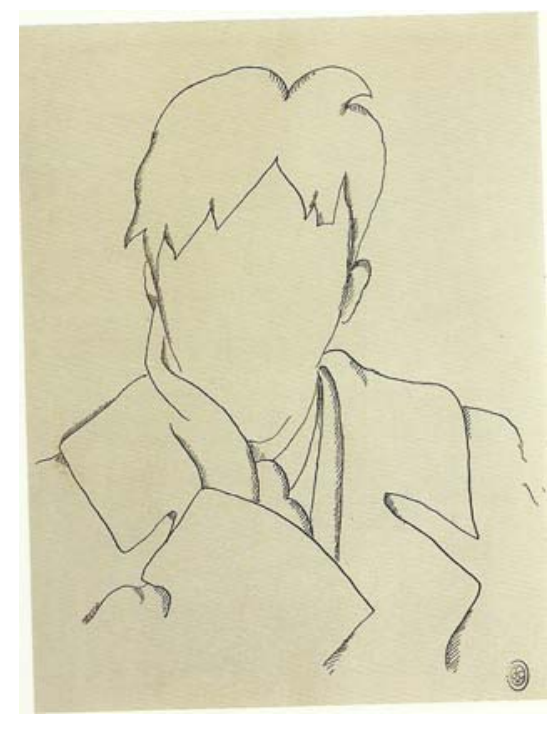

FIG. 10 - Autoportrait sans visage, [s.d]. Desenho, 28x22. Coleção Marie-Yvonne de Saint-Georges.

É interessante pensar nos desdobramentos de tais ausências. Aliás, para DidiHuberman, "não há portanto imagem dialética sem um trabalho crítico da memória,

\footnotetext{
${ }^{14}$ COCTEAU. La difficulté d'être, p. 31, tradução nossa.

${ }^{15}$ PAÏNI. L'homme invisible, p. 279.
} 
confrontada a tudo que resta como indício de tudo o que foi perdido.”16 Dessa maneira, Cocteau teria tornado cada um dos desenhos da sua série de autorretratos sem rosto mais forte que o seu autorretrato convencional de 1913 (Fig. 1) e esse desenho sem data (Fig. 10) acrescentaria à questão “Quem sou eu?” uma dúvida temporal: quando fui assim?

Em seu filme Le testament d'Orphée, ${ }^{17}$ de 1959, o poeta esfrega um tecido em uma tela preta para, ao invés de apagar, fazer aparecer o desenho de um hibisco, mas o que surge é o seu autorretrato, desta vez com os traços definidores da sua fisionomia, agora, a de um homem com sessenta anos de idade. Nesse momento da cena, a personagem de Cégeste, interpretada pelo seu filho adotivo, Édouard Dermit, diz que “um pintor pinta sempre o seu autorretrato”. A cena torna-se, assim, emblemática, num filme que tem como segunda opção de título um quase desabafo impotente do autor: "não me pergunte por quê".

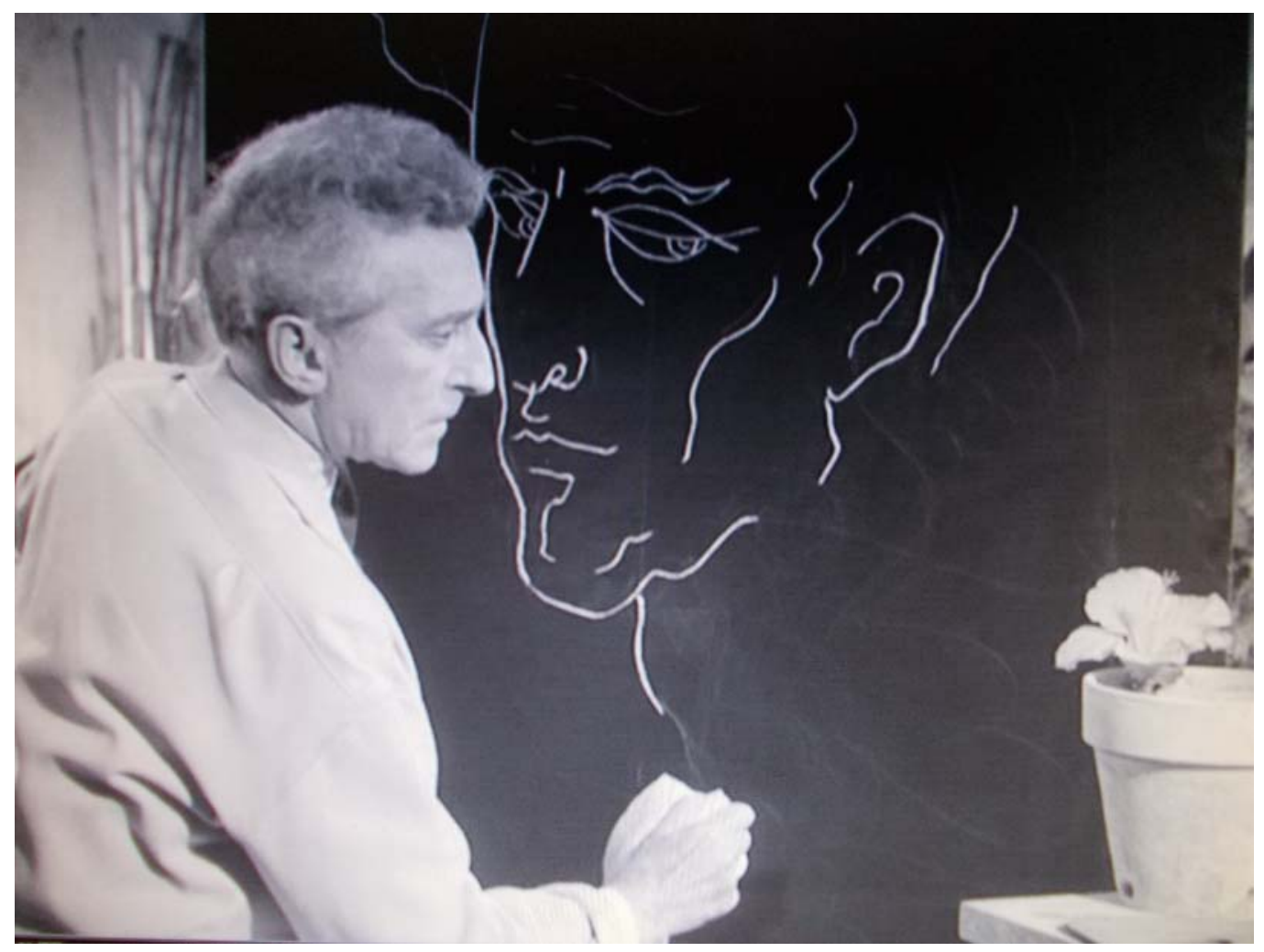

FIG. 11 - O testamento de Orfeu, direção de Jean Cocteau, 1959.

Vê-se aí que, como na série dos autorretratos sem rosto, a questão da identidade permanece complexa na obra de Cocteau e intimamente ligada à questão da memória, já que é em sua base uma questão de história pessoal, interpessoal, familiar e social.

\footnotetext{
${ }^{16}$ DIDI-HUBERMANN. O que vemos, o que nos olha, p. 174.

${ }^{17}$ COCTEAU. Le testament d'Orphée.
} 
A obra de arte autobiográfica tem vários pontos em comum com a autobiografia literária. As duas afirmam a existência de uma relação entre o sujeito que conta (o autor), a vida (ou um episódio da vida) e a obra que a descreve. O narrador ou a narradora em primeira pessoa se lembra da sua vivência e fala disso, seja através de breves descrições ou simples alusões. ${ }^{18}$

Dessa forma, do autorretrato, enquanto imagem do próprio autor, espera-se a revelação de uma identidade, de uma vida, recompostas por traços e elementos resgatados pela memória desse autor. É por isso que, quase sempre, o espectador cai na armadilha do gênero, pois como ainda afirma Steiner e Yang:

Nas artes plásticas como na literatura, a fronteira entre o real e a ficção é tão permeável que se torna, geralmente, impossível distingui-los. De toda maneira, o próprio processo de se voltar para o passado provoca, automaticamente, uma distorção da realidade. Ainda que nenhuma autobiografia tenha a pretensão da 'verdade', o autor aspira, por convenção, a fornecer uma aproximação convincente da verdade. [...] certos artistas questionam abertamente essa tentativa e inserem, em seu 'relato', índices que revelam seu caráter fictício. ${ }^{19}$

O autor firma um pacto, como o "pacto autobiográfico" definido por Philippe Lejeune, ${ }^{20}$ no momento em que intitula sua obra como "autoportrait", mas não se deve esquecer que se trata de uma construção, da construção da "sua verdade", de uma verdade filtrada pela sua memória ou ainda, da verdade que ele é capaz de aceitar e expor. A "verdade” do autor constitui uma narrativa, seja ela um texto ou uma imagem, pois todas as imagens estão de alguma forma relacionadas entre si e há relações no interior de cada imagem.

Formalmente, os relatos existem no tempo e as imagens no espaço. Durante a Idade Média, em um único retábulo podia-se representar toda uma sequência narrativa, incorporando o fluir do tempo dentro dos limites de um marco espacial, como em nossas tirinhas humorísticas, com uma mesma personagem que aparece repetidas vezes em uma paisagem unificadora à medida que ele ou ela avança na trama narrativa da pintura. Com o desenvolvimento da perspectiva no Renascimento, os quadros se imobilizaram em um instante único: o do momento em que a imagem é percebida do ponto de vista de um espectador determinado. O relato se transmitia, então, por outros meios: mediante 'o simbolismo, as poses dramáticas, as alusões à literatura, os títulos', isto é, mediante outras fontes que revelavam ao espectador o que ocorria. ${ }^{21}$

\footnotetext{
${ }^{18}$ STEINER; YANG. Autobiographie, p. 16, tradução nossa.

${ }^{19}$ STEINER; YANG. Autobiographie, p. 16, tradução nossa.

${ }^{20}$ LEJEUNE. Le pacte autobiographique.

${ }^{21}$ MANGUEL. Leer imágenes. Una historia privada del arte, p. 27, tradução nossa.
} 
É dessa forma que Cocteau revela um pouco da sua história, mesmo quando tenta esconder alguns elementos, como os traços do seu rosto. Ele acaba por revelar, por exemplo, que se veste com esmero, que faz parte de uma classe social favorecida e até mesmo que o paradoxo da sua exposição extrema e da sua “invisibilidade” é um tema importante para ele. Não bastasse todas as leituras possíveis dos seus autorretratos sem rosto, ele produziu, ainda, um desenho intitulado Quadruple autoportrait (quádruplo autorretrato), de 1915-1916, no qual cria um jogo narrativo em imagens.

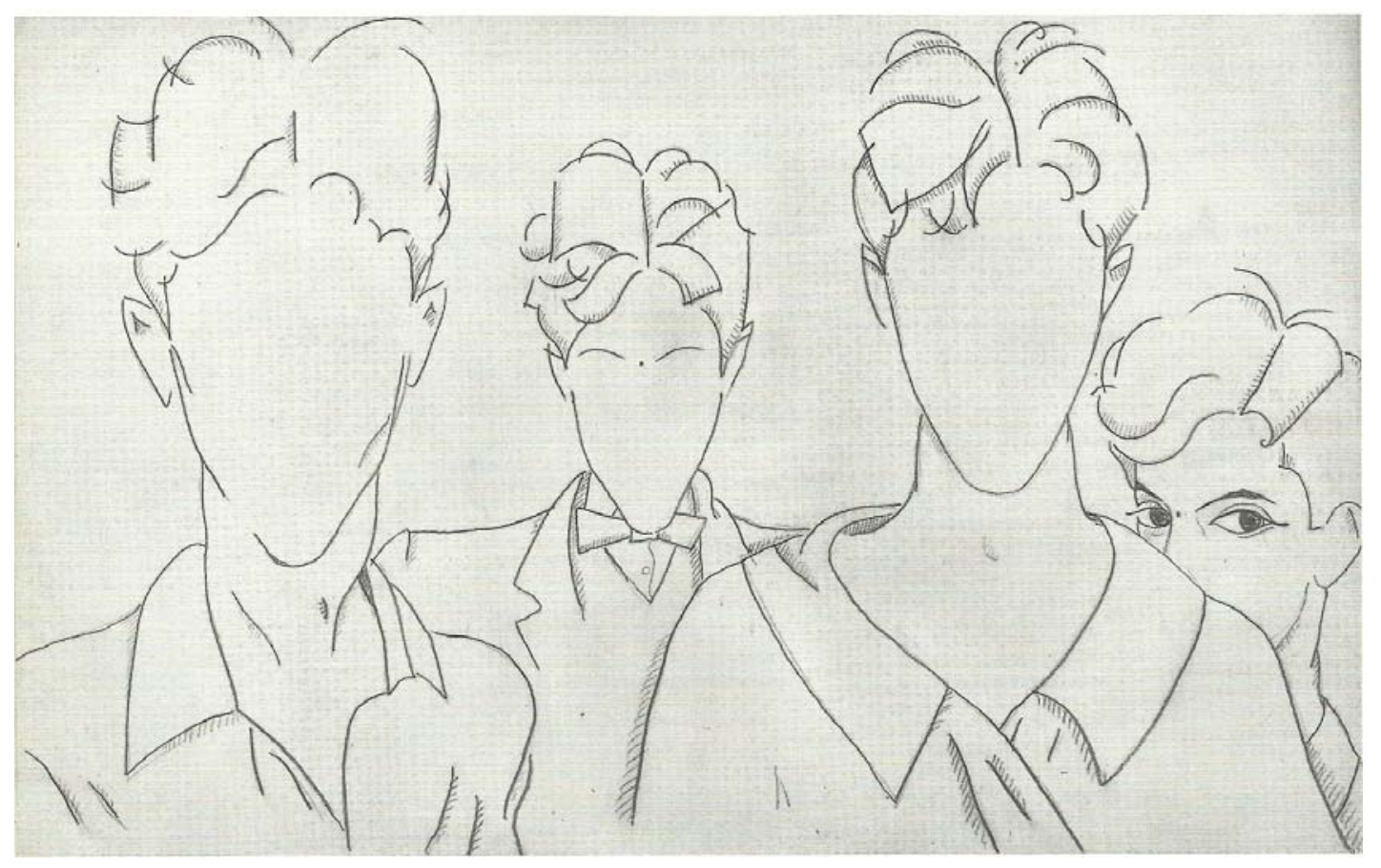

FIG. 12 - Quadruple autoportrait, 1915-1916. Desenho, 29x45. Coleção particular.

Numa mesma obra, quatro retratos do autor. Cada um ocupa um plano diferente. Guardando o estilo Cocteau, cada um usa uma roupa diferente. Um tem o rosto completamente vazio de traços. O segundo tem apenas dois traços discretos no rosto. $\mathrm{O}$ terceiro apresenta as sobrancelhas e uma pinta entre elas. Já o quarto tem seus olhos bem desenhados fixos no espectador. Mas, a quarta personagem se esconde atrás da primeira, numa atmosfera de mistério, numa atitude quase desafiadora e, certamente, de cumplicidade entre todas elas.

Como nos retábulos medievais, pode-se ler uma história constituída das diferenças das quatro representações de Cocteau no desenho. Como na Renascença, pode-se, também, fazer uma leitura contínua dessa repetição apresentada numa única folha de papel, pois se tem, aí, a criação de planos e profundidade e a relação estabelecida entre cada Cocteau autorrepresentado com suas sutis, mas significativas, diferenças. Então, cabe ao espectador, 
de posse ou não de informações sobre a biografia do poeta, desvendar a história inscrita na imagem.

Em todo caso, parece-me evidente que o autorretrato é um exemplo pertinente da questão “identitária” e que a identidade está intimamente relacionada com a memória. No caso particular de Jean Cocteau, a sua série de autorretratos sem rosto extrapola essa questão, atingindo o status de uma imagem crítica e, com isso, levando o espectador a questionar a imagem produzida pelo poeta e a estrutura do próprio gênero autorretrato. Um questionamento que passa, necessariamente, pelas noções de esquecimento, apagamento ou provocação estética. Além disso, com esta análise procuro destacar, também, como o Cocteau desenhista guarda a sua verve de escritor e cineasta criando imagens que se dão a ler como narrativas. Através dos autorretratos analisados, vislumbram-se dados da vida do poeta, como sua classe social e o seu gosto pela moda, mas, também, a sua inquietação acerca de ser visto e de ser reconhecido. No entanto, ainda que o pacto firmado através do título dos desenhos seja de retrato do autor, não se deve esquecer que se trata de um "eu” construído para ser exibido como uma imagem de Cocteau.

\section{RÉSUMÉ}

Artiste pluridisciplinaire, le poète français Jean Cocteau bâtit une oeuvre dont l'expression du "moi” est un thème central. Cet article se propose donc une réflexion autour des questions suscitées par une série d'autoportraits que l'auteur réalisa entre 1910 et 1917, telles que l’identité, l'image, la mémoire et le récit.

\section{MotS-CLÉS}

Jean Cocteau, autoportrait, identité, image, mémoire

\section{REFERÊNCIAS}

BONAFOUX, Pascal. Autoportraits du XXe siècle. Look at me. Paris: Gallimard, 2004.

BURKE, Peter. Testemunha ocular: história e imagem. Trad. Vera Maria Xavier dos Santos. Bauru, SP: EDUSC, 2004.

CALMÉJANE, Yves. Histoire de moi ou l'histoire des autoportraits. Paris: Thalia Édition, 2006. 
COCTEAU, Jean. La difficulté d'être. Paris: Éditions du Rocher, 1989.

DIDI-HUBERMANN, Georges. O que vemos, o que nos olha. Trad. Paulo Neves. São Paulo: Ed. 34, 1998.

LEJEUNE, Philippe. Le pacte autobiographique. Paris: Seuil, 1996.

LE TESTAMENT D’ORPHÉE. Direção de Jean Cocteau. França: 1959. Studio Canal, 1 DVD (116 minutos), preto e branco.

MANGUEL, Alberto. Leer imágenes. Una historia privada del arte. Trad. Carlos José Restrepo. Madrid: Alianza, 2003.

PAÏNI, Dominique. L'homme invisible. In: COCTEAU, Jean. Jean Cocteau sur le fil du siècle. Paris: Éditions du Centre Pompidou, 2003. 416 p. Catálogo de exposição, 25 set. 2003 - 5 jan. 2004, Centre Pompidou; 6 maio - 29 ago. 2004, Musée des Beaux-Arts de Montréal. p. 279-280.

REBEL, Ernst. Autoportraits. Colônia: Taschen, 2008.

STEINER, Barbara; YANG, Jun (Dir.). Autobiographie. Trad. Michèle Hechter. Paris: Thames 7 Hudson, 2004.

TEIXEIRA COELHO. Olhar e ser visto na Casa Fiat de Cultura. A figura humana da Renascença ao contemporâneo. São Paulo: Museu de Arte de São Paulo, 2011. 96 p. Catálogo de exposição, 3 maio-3 jul. 2011, Casa Fiat de Cultura, Belo Horizonte, p. 32-42.

Remerciement d’usage: “Comité Jean Cocteau”.

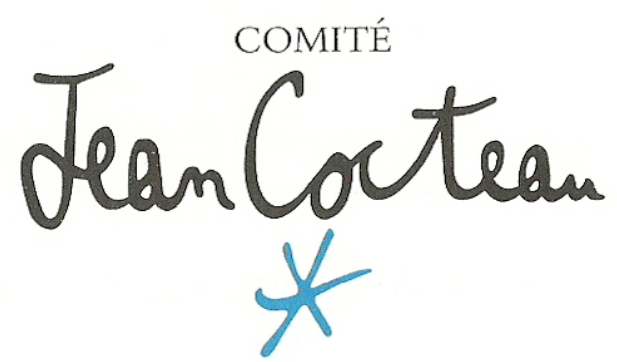

